\title{
Implementation of Internal Quality Assurance to Improve the Quality of Islamic Education
}

\author{
Indah Komsiyah'
}

DOI: $10.35445 /$ alishlah.v13i3.1341

Article Info

Keywords:

Education;

Primary School;

Quality Assurance;

Kata kunci:

Pendidikan;

Sekolah Dasar;

Penjaminan Mutu

\section{Abstract}

The purpose of this study was to examine the implementation of internal quality assurance of Madrasah Aliyah Amanatul Ummah International Standard to improve the quality of education as one of the international-based Madrasah. There were 30 participants involved in this study, of consisted of 1 Kiai, one madrasah head, one deputy coordinator of Madrasah, 27 teachers (ustads). They were selected by using purposive sampling. This research was a case study research design with a single case study model in qualitative research. The qualitative data were collected by using observation, documents and interviews. The data analysis technique used three activity flows that occurred simultaneously, namely; 1) data reduction; 2) data display, and 3) concluding/verification. The results of data analysis indicated that the quality assurance process has an orderly flow by Standard Operating Procedures. The process started from setting evaluation standards, implementing evaluations, monitoring, self-evaluation, auditing internal academic quality as a whole, formulating corrections, and improving quality. This cycle was carried out continuously. Quality assurance improved the quality of Islamic education. It had a positive impact on sustainable quality assurance and the commitment of stakeholders to achieve quality education.

\begin{abstract}
Abstrak
Tujuan penelitian ini adalah untuk mengkaji penerapan penjaminan mutu internal madrasah Aliyah Amanatul Ummah Berstandar Internasional untuk meningkatkan mutu pendidikan sebagai salah satu madrasah yang berbasis internasional. Partisipan penelitian berjumlah 30 orang, terdiri dari 1 kiai, 1 kepala madrasah, 1 wakil koordinator madrasah, 27 guru (ustad). Mereka dipilih menggunakan purposive sampling. Penelitian ini merupakan penelitian studi kasus dengan model penelitian studi kasus tunggal dalam penelitian kualitatif. Data kualitatif dikumpulkan dengan menggunakan observasi, dokumen dan wawancara. Teknik analisis data menggunakan tiga alur kegiatan yang terjadi secara bersamaan, yaitu l) reduksi data; 2) tampilan data; dan 3) kesimpulan/verifikasi. Hasil analisis data menunjukkan bahwa proses penjaminan mutu telah berjalan dengan tertib sesuai Standar Operasional Prosedur. Prosesnya dimulai dari penetapan standar evaluasi, pelaksanaan evaluasi, pemantauan, evaluasi diri, audit mutu internal akademik secara keseluruhan, perumusan koreksi, dan peningkatan mutu. Siklus ini dilakukan secara terus menerus. Penjaminan mutu telah meningkatkan mutu pendidikan Islam. Hal tersebut berdampak positif terhadap penjaminan mutu yang berkelanjutan dan komitmen pemangku kepentingan untuk mewujudkan pendidikan yang berkualitas.
\end{abstract}

\footnotetext{
${ }^{1}$ Universitas Islam Negeri Sayyid Ali Rahmatullah, Tulungagung, Indonesia

Email: indahkomsyah@yahoo.com
}

Vol.13 (3) December 2021.

Received: November 17, 2021; Received in revised form: December 8, 2021; Accepted: December 12, 2021; Available online: December 25, 2021. This is an open-access article under a Creative Commons Attribution-NonCommercial-ShareAlike 4.0 International License 


\section{INTRODUCTION}

Science and technology advancements have influenced changes in human life. So that they are required to be able to adapt to these changes. In this case, educational institutions, including elementary schools, must pay attention to the quality level of education to enhance human resources quality. The main focus of quality education was educational equity, educational quality, educational relevance, and educational management efficiency- (Idrus, 2012). From elementary school to university level, every educational institution should ensure educational quality. This quality assurance is related to the school's overall activities. This quality assurance activity has numerous advantages for educational implementation. Internally, it can improve educational quality, generate enthusiasm among the school's academic community, and foster a quality culture. Meanwhile, externally, this quality assurance process prepares for carrying out national accreditation or shaping the community's image of school organizations' quality level (Sulaiman \& Wibowo, 2016). As a form of public accountability, school accreditation is an evaluation of the viability of a comprehensive education program about the National Education Standards (Awaludin, 2017). Thus, it can be concluded that the quality assurance process is a must for educational institutions to improve the quality of education

As a result, schools continue to have external quality standards. Meanwhile, the school's internal quality assurance is carried out by the school's needs. Education quality assurance is a systematic and integrated activity carried out by an educational unit or program and its implementers, regional and central governments, and the community to improve the nation's intelligence through education. Implementing the school's Internal Quality Assurance Standards can begin with quality mapping, planning for quality compliance, implementing quality compliance, evaluating and setting standards, and so on (Rahmania et al., 2020). The importance of quality assurance in improving the quality of educational services is related to the quality standards and the efforts or systems to achieve these standards.

Therefore, Amanatul Ummah International-Based Madrasah in Pacet Mojokerto is also working on quality assurance to ensure that the education is relevant to the current conditions. According to the findings of the interview with the Deputy Coordinator of Amanatul Ummah Madrasah, this Madrasah has a special flagship program that has been accredited A. Students who pass the national exam are accepted into domestic and international universities with full scholarships. In addition to these academic achievements, the madrasahs have produced brilliant students at the local, regional, national, and international levels. The researchers' preliminary observations also found that almost all students at Madrasah Amanatul Ummah conducted and experienced the learning process in a fun way. The specific location or location in a mountainous area is an important reason why the teaching and learning process in Madrasah were conducted pleasantly. The teaching system is organized by combining three curricula at once, namely the National curriculum, the Mu's curriculum from al-Azhar Egypt, and the Cambridge curriculum. From these conditions, it can be seen that internal quality assurance in Madrasah Amanatul Ummah is an important aspect of education. Quality Assurance is very important to be applied in Islamic education, especially Islamic boarding schools, so that pesantren can survive and continue to exist in the current era of modernity.

There were previous studies that have been conducted related to quality assurance. Quality Assurance is very important to be applied in Islamic education, especially Islamic boarding schools, so that pesantren can survive and continue to exist in the modern era. Quality assurance is also expected to produce information that can be used as feedback for schools as well as assure parents that the school always strives to provide the best service for its students (Fathurrohman, 2019). Munastiwi (2015) has studied quality assurance in a vocational school. It used Holistic Skills Education (HOLSKED), which manifests the education quality assurance process. Meanwhile, Sofoluwe \& Akinsolu (2015) involves community participation in education quality assurance activities. Since the implementation of quality assurance in schools requires the participation of all parties both inside and outside the school, managers need to have communication skills and motivation that can build awareness in quality assurance (Thanomwan \& Dhatthakan, 2014). In Thailand, the quality assurance system model has 
provided changes consisting of 1) reduction of misconceptions of the quality assurance process, 2) needs assessment of the quality assurance process, 3) support from all stakeholders, and 4) development of executive leaders. There are 55 elements of the quality assurance process; needs assessment, planning, implementation, audits and assessments (Ajpru et al., 2014). Another element of the influence of quality assurance can also be understood from the quality of reporting on educational activities (Maroun, 2019).

Several previous studies show that internal quality assurance has a very important role in the implementation of quality education. In this case, many factors affect the success of the implementation of internal quality assurance (Praraksa et al., 2015). It means that madrasas are undergoing transformations that will positively impact education quality. The challenges and opportunities that arise in implementing these approaches in quality assurance include changes in the quality assurance approach at each stage and encapsulating the appropriate system structure.

This research aimed to examine the internal quality assurance of madrasah Aliyah Amanatul Ummah International Standard to improve educational quality as one of the international-based Madrasah. The findings of this study were expected to benefit madrasahs and other Islamic educational institutions by demonstrating how to conduct internal quality assurance for madrasahs. As a result, every educational institution can adapt internal quality assurance methods from educational implementation to improve educational quality.

\section{METHODS}

The study participants were 1) kyai, 2) madrasa heads, 3) vice coordinators of Madrasas, and 4) ustadz or teachers in Madrasas Aliyah. It was taken using purposive sampling. Here is the demographic of participants;

\begin{tabular}{lcccc}
\hline \multicolumn{1}{c}{ Informant's Profile } & Kyai & Madrasah Head & Vice Coordinators of Madrasa & Teachers \\
\hline Gender: & & & & \\
Male & 1 (ASC) & $1(\mathrm{AC})$ & $1(\mathrm{RI})$ & 12 \\
Female & - & - & - & 15 \\
& & & - & - \\
Age: & - & - & - & 12 \\
Less than 25 & - & - & 1 & 15 \\
$26-35$ & - & 1 & - & - \\
$36-45$ & 1 & - & & \\
Over than 46 & & & - & 3 \\
Academic: & - & - & 1 & 12 \\
PhD & 1 & 1 & - & 15 \\
Master & - & - &
\end{tabular}

This research was a case study designed with a single case study model in qualitative research. This study related to the subjectivist and interpretive approach (Creswell, 2012). The study was conducted at Amanatul Ummah International Standard Madrasa Aliyah Pacet Mojokerto, East Java. The process of collecting data used observation, document and interview. An observation checklist was done by visiting the Madrasah. Document used to identify the quality assurance that was taken from the report of education program, the result of accreditation, and the result of supervision. The interviews were done with 1) kyai, 2) madrasa heads, 3) vice coordinators of Madrasas, and 4) ustadz or teachers in Madrasah to get information about quality assurance. The data analysis technique used three activity flows that occurred simultaneously, namely, 1) data reduction, 2) data display, and 3) conclusion drawing/verification. Here is the design of the study. 


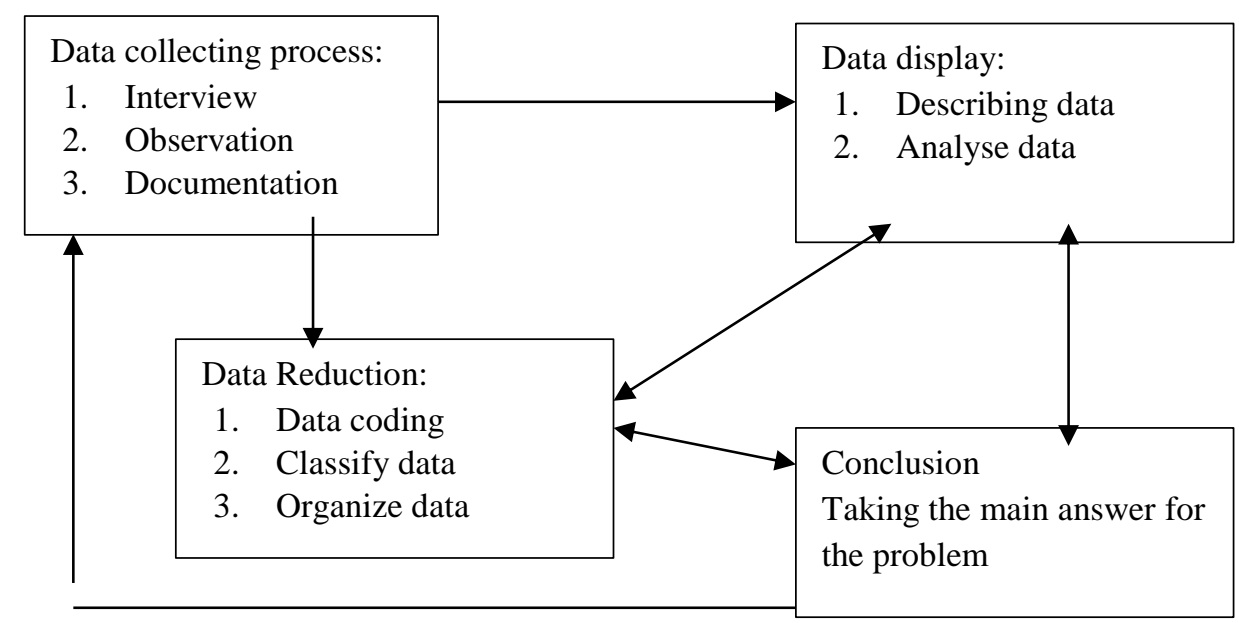

\section{FINDINGS AND DISCUSSION}

The results of data analysis from observations and documents that have been carried out that the quality assurance process at the International-Based International Amanatul Ummah Madrasah is illustrated in the following cycle.



Figure 1. A cycle of Quality Assurance in International-Based International Amanatul

\section{Ummah Madrasah}

Figure 1 shows some of the actions in the quality assurance are;

1. Standard Operating Procedures determine standard operational documents in implementing quality assurance.

2. The implementation of quality assurance is a series of evaluation processes for all educational activities. In this section, the head of the Madrasah shows visionary leadership as a top leader, management commitment in integrating the system applied by Islamic boarding schools with Madrasah. Quality improvement teams measure for teachers and students to set cost standards that are not expensive and affordable for all groups.

3. Units carry out monitoring at the higher level or related units in evaluating processes and results.

4. Evaluation of quality assurance activities is carried out regularly, either every week, month, or year

5. The Internal Academic Quality Audit activity findings were used as evaluation data.

6. The Continuous Quality Improvement at all levels of the academic implementation unit is carried out as a manifestation of continuous quality improvement.

The interview data showed that International-Based International Madrasah Aliyah Amanatul Ummah had taken a quality process that is realized with the quality standards initiated by the caregivers of the Islamic boarding school as a leader with a high position in the Islamic boarding school. It is used as an idea to make a program. The following steps are were taken to implement quality assurance; 
1. Build management commitment

Management's commitment to quality assurance at the International-Based International Amanatul Ummah Madrasah has shown a combination of the system applied by Islamic boarding schools and madrasahs. The planning of a quality assurance system at an Internationally-Based International Amanatul Ummah Madrasa is usually planned in a joint meeting by Kiyai and Mudhirul Ma'had together with the ustadz. Concerning the planning of the quality assurance system, Ustad Rozi explains in his question below.

"The plan for the quality assurance system at MBI is usually planned in a meeting. The meetings held at MBI include annual work meetings, monthly work meetings, weekly or weekly meetings and subject teachers' meetings. This annual working meeting was attended by education and educational staff within the International-Based International Amanatul Ummah Madrasah as well as foundation administrators, namely Kyai Asep and other foundation administrators. Next is a monthly working meeting which is attended by all the academic community. Then the weekly meeting was attended by homeroom teachers and supervisors. The last meeting was the Subject Teacher Deliberation meeting by presenting their respective subject teachers".

The next series of management commitments set quality standards for students so that students can compete in this modern era and be accepted by the community. Internationally-Based Amanatul Ummah Madrasah in quality assurance carry out the management commitment process as follows, 1) form a commitment to religious culture through the internalization of transformational values in daily life; 2) leadership acts as an inspiration, promoter, controller and controller; 3) impose strict sanctions on violations of commitments based on the applicable regulations. For example, when a student violates a commitment not to smoke, but the student violates that commitment, the sanction is to be sent home to be fostered by his parents for approximately two weeks to a month, and 4) the commitments that are mutually agreed at the International-Based International Amanatul Ummah Madrasa are in the academic and nonacademic fields.

2. Empowering the quality improvement team.

3. The quality measures of the International-Based Madrasah Amanatul ummah can be traced based on the exposure to the findings above. One of them is forming a quality improvement team. The team is formed through the following processes, 1) the education quality improvement team formed consists of teachers in coordination with subject teachers; 2) the quality improvement team at the Amanatul ummah International-Based Madrasah Amanatul Ummah carries out the task of planning learning programs to its supervision; 3) Islamic boarding schools monitor and monitor teacher discipline as a quality improvement team through teaching journals.

4. Streamlining evaluation activities. The evaluation process is carried out through the following steps. First, through the placement selection path. Second, through the matriculation program. This program is carried out based on the diversity of students' backgrounds related to students' study abilities and experiences, especially mastery of religious material and mastery of Arabic and English. Third, the foreign language development program is both Arabic and English in daily communication. Fourth, the system of coaching and supervising students for 24 hours (24 hours care system). Fifth, the cycle program or repetition. In addition to language strengthening programs and 24-hour coaching patterns.

5. Establish affordable financing (cost quality). International-Based Madrasah Amanatul ummah makes the standard cost of education for students is not expensive so that it is affordable by all people.

6. Quality conscious. One of the ways to implement quality awareness in Amanatul ummah International-Based Madrasah is through evaluation of the journal system and the obligation to spend material.

7. Effectively learning the integration of science in Islam. 
Based on the data findings, the implementation of quality assurance at Madrasah Aliyah Amanatul ummah Internationally has been carried out by the operational procedures owned by the madrasa as described in Figure 1. Every activity in the quality assurance process impacts improving the quality of education in madrasas. Each step of the quality assurance process is carried out sequentially and patterned according to operational quality assurance standards. In this case, it can be understood that the quality assurance of an educational institution has the steps that have been set in the rules (Lo, 2014). Thus, the implementation of quality assurance can provide positive changes and impacts on the quality of education. Educational institutions can also face challenges and opportunities to make quality changes(Kerimkulova \& Kuzhabekova, 2017; Sari et al., 2016).

The implementation of quality assurance in Madrasah Aliyah Amanatul Ummah can be seen in the commitment of school management. Every department involved in the implementation of education at the Amanatul Ummah madrasah has good and structured coordination. The right team units always carry out various educational programs and activities and cooperate closely to achieve quality in the educational process properly. In addition, quality assurance also impacts the quality of good teamwork between teachers, principals, foundations, students, and other academic departments. Each result of this quality assurance process becomes the evaluation material for madrasas in improving the quality of education.

\section{CONCLUSION}

The internal quality assurance had a positive impact on the quality education process in madrasah aliyah Amanatul Ummah. Internal quality assurance measured for education at the International-Based Madrasah Aliyah Amanatul Ummah Pacet Mojokerto was based on Islamic values and are carried out through 1) superior programs on an ongoing basis; 2) meeting the quality improvement criteria that the institution has internally determined; 3) performing a series of cycles in an accountable manner, and 4) meeting the standards outlined as an international standard institution by combining science and Ismaili values.

The findings of this study had implications for understanding the concept of educational institutions' existence. Islamic educational institutions, particularly formal educational institutions in Islamic boarding schools, must be prepared to make changes due to various factors and threats through regular internal quality assurance measures. As a result, Islamic educational institutions must be prepared to change at any time. Improving the quality, existence, and competitiveness of the community and the world of education today must be the driving force for changes and innovations in educational implementation.

The researcher realizes that this research has several limitations. Research activities are only focused on knowing the implementation of internal quality assurance to improve the quality of education in madrasah aliyah. Therefore, the results of this study can still be developed in other aspects, such as the framework of cooperation from each stakeholder involved in quality assurance. It is very important to carry out additional research, especially on improving the quality of schools in Islamic boarding schools, to increase competitiveness. The internalization of the pesantren tradition in informal schools in the pesantren environment is an important point that must be studied.

\section{REFERENCES}

Ajpru, H., Wongwanich, S., \& Khaikleng, P. (2014). Design of Educational Quality Assurance System for Driving Policy of Educational Reform in Thailand: Theory-based Evaluation. Procedia - Social and Behavioral Sciences, 116, 1416-1422. https://doi.org/10.1016/J.SBSPRO.2014.01.408

Awaludin, A. A. R. (2017). Akreditasi Sekolah sebagai Suatu Upaya Penjaminan Mutu Pendidikan di Indonesia. SAP (Susunan Artikel Pendidikan), 2(1). https://doi.org/10.30998/SAP.V2I1.1156

Creswell, J. W. (2012). Research, educational planning, conducting, and evaluating quantitative and qualitative research. Pearson Education.

Fathurrohman, M. (2019). Quality Assurance di Lembaga Pendidikan. Kalimedia. 
Idrus, M. (2012). Mutu Pendidikan Dan Pemerataan Pendidikan Di Daerah. PSIKOPEDAGOGIA Jurnal Bimbingan Dan Konseling, 1(2). https://doi.org/10.12928/psikopedagogia.v1i2.4603

Kerimkulova, S., \& Kuzhabekova, A. (2017). Quality Assurance in Higher Education of Kazakhstan: A Review of the System and Issues. The Rise of Quality Assurance in Asian Higher Education, 87108. https://doi.org/10.1016/B978-0-08-100553-8.00006-9

Lo, W. Y. W. (2014). Think global, think local: The changing landscape of higher education and the role of quality assurance in Singapore. Policy and Society, 33(3), 263-273. https://doi.org/10.1016/J.POLSOC.2014.09.002

Maroun, W. (2019). Does external assurance contribute to higher quality integrated reports? Journal $\begin{array}{llll}\text { of Accounting Public } & \text { Policy, } & \text { 38(4), } & 106670 .\end{array}$ https://doi.org/10.1016/J.JACCPUBPOL.2019.06.002

Munastiwi, E. (2015). The Management Model of Vocational Education Quality Assurance Using 'Holistic Skills Education (Holsked).' Procedia - Social and Behavioral Sciences, 204, 218-230. https://doi.org/10.1016/j.sbspro.2015.08.144

Praraksa, P., Sroinam, S., Inthusamith, M., \& Pawarinyanon, M. (2015). A Model of Factors Influencing Internal Quality Assurance Operational Effectiveness of the Small Sized Primary Schools in Northeast Thailand. Procedia - Social and Behavioral Sciences, 197, 1586-1590. https://doi.org/10.1016/J.SBSPRO.2015.07.115

Rahmania, I., Budiono, B., Soenaryo, S. F., Syakur, A., \& Tinus, A. (2020). Implementation of Internal Quality Guarantee System to Increase the Quality of Education in Junior High School 21 Malang. Budapest International Research and Critics in Linguistics and Education (BirLE) Journal, 3(1), 421-432. https://doi.org/10.33258/BIRLE.V3I1.838

Sari, A., Firat, A., \& Karaduman, A. (2016). Quality Assurance Issues in Higher Education Sectors of Developing Countries; Case of Northern Cyprus. Procedia - Social and Behavioral Sciences, 229, 326-334. https://doi.org/10.1016/J.SBSPRO.2016.07.143

SOFOLUWE, A. O., \& AKINSOLU, A. O. (2015). Community Participation in Quality Assurance (CPQA): A Catalyst in Enhancing Quality Basic Education Service Delivery in Nigeria. Journal of Education and Practice, 6(7), 12-19.

Sulaiman, A., \& Wibowo, U. B. (2016). Implementasi Sistem Penjaminan Mutu Internal Sebagai Upaya Meningkatkan Mutu Pendidikan Di Universitas Gadjah Mada. Jurnal Akuntabilitas Manajemen Pendidikan, 4(1), 17. https://doi.org/10.21831/amp.v4i1.8197

Thanomwan, P., \& Dhatthakan, P. (2014). Relationship between Administrators' Competencies and Internal Quality Assurance. Procedia - Social and Behavioral Sciences, 116, 808-814. https://doi.org/10.1016/J.SBSPRO.2014.01.302 
Al- Ishlah: Jurnal Pendidikan, December 2021, 13 (3), Pages 2241-2248 Indah Komsiyah

This page is intentionally left blank 